\title{
ANALYSIS OF FINANCING RISK USING CREDIT SCORING ON MICROFINANCE: A CASE STUDY IN X ISLAMIC BANK
}

\author{
Safitri Dayu*, Novianti Tanti, Sartono Bagus \\ School of Business, IPB University, Indonesia \\ *E-mail: dayusafitri@gmail.com
}

\begin{abstract}
Credit scoring is a tool used to measure and predict the financing risk for the financing to be provided. An inaccurate scoring model will increase the financing risk. This study aims to examine the credit scoring used by $\mathrm{X}$ Islamic Bank, by using the logistic regression test. The results showed that from the 11 variables used, only 4 variables significantly affect the quality of financing and the $\mathrm{R}$ Square of the model is $2.3 \%$.
\end{abstract}

\section{KEY WORDS}

Credit scoring, financing risk, Islamic bank, microfinancing.

Small and Medium Entreprises (SMEs) have an important role in the economy of a country. Therefore, SMEs needs to be constantly developed and empowered. Support is necessary from various parties to realize competitive SMEs in the free market. Such support is beneficial for SMEs in maintaining a business when the country's economy is hit by a crisis.

Islamic Banking is a financial institution that becomes a mediator between those who have excess funds and lack of funds. The role of Islamic Banking, in general, is to be able to provide benefits to all people. The SMEs actors can utilize the existence of Islamic Bank in developing business, especially helping the problem of limited capital through a product called microfinance. Microfinance is financing intended for people with a business of 2 years minimum. The bank will experience several risks when conducting financing disbursement, one of which is financing risk.

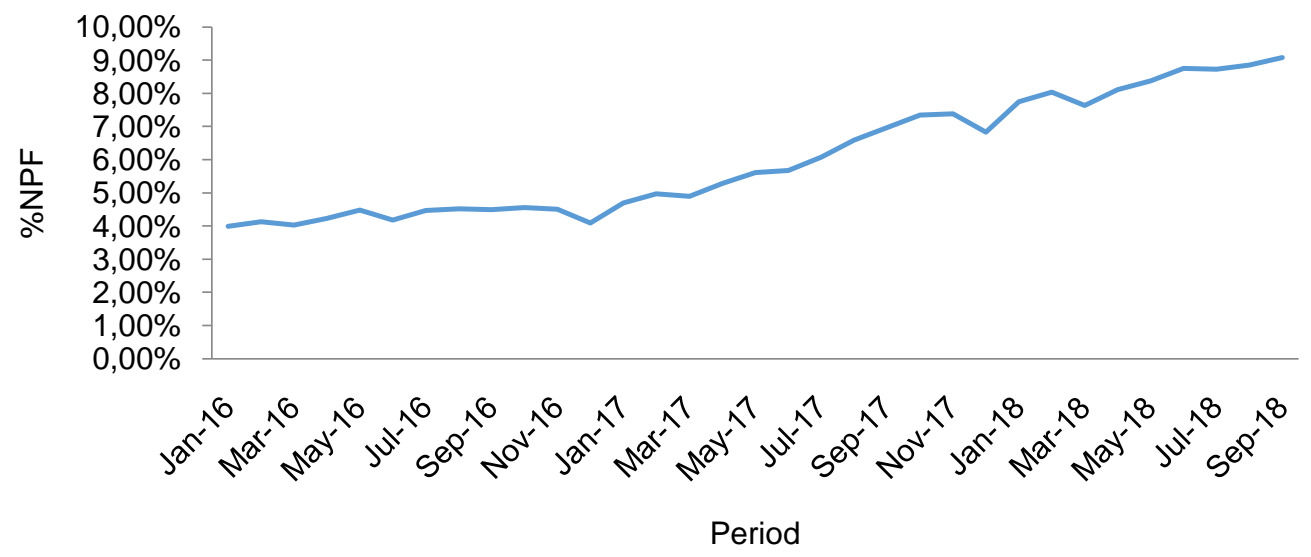

Figure 1 - Level of Non-Performing Financing (NPF) of Micro Financing in X Islamic Bank

In terms of financing risk, bad financing is the source of loss for $X$ Islamic Bank. Nonperforming finance in banks is the total financing quality is in the substandard, doubtful, and bad category. The NPF level can be obtained through a comparison between the number of problem financing and total financing. $X$ Islamic Bank has a quite high NPF level because it is above the bank's health standard set by the Indonesian Bank at 5\%.

Islamic Bank must be able to manage financing risk due to the potential failure of other parties in fulfilling their agreed obligations. Risk mitigation performed by $\mathrm{X}$ Islamic Bank at 
the beginning of financing is by applying credit scoring used to attract prospective customers who are eligible for financing. According to Andhayani (2009), the ability of the credit scoring model as a tool to perform the financial analysis is useful as the first step in mitigating the failure of obligation fulfillment by the customer. Credit scoring is widely used in financing risk management to forecast the obstacles that customer will repay the financing. The purpose of credit scoring is to predict the risk rather than explain a risk. The important point is that credit scoring is a prediction of risk and does not explain why some customers are default while others are not. However, credit scoring needs to be reviewed periodically to see the level of accuracy and to see less significant factors.

\section{LITERATURE REVIEW}

According to Ascarya and Yumanita (2005), the basic principle of Islamic banking is to follow the Islamic rules which are free from MAGHRIB (maysir, gharar, riba, and bathil). Financing is the provision of money based on contracts between banks and customers who are obliged to return the money within a certain period of time with agreed upon profit sharing (Permata et al. 2014). Ibrahim and Ghazali (2014) defined microfinance as providing financing for the poor to help them rise from poverty through entrepreneurship.

According to $\mathrm{BI}$ (2011), the risk is the potential loss due to the occurrence of certain events. Risk management is essentially a series of methodologies and procedures used to identify, measure, mitigate, monitor and control risks arising from all bank business activities. Risk management is an effort to manage risk to realize the opportunity to get profits sustainably because the risks to the bank's activities are taken into account.

According to Khan and Ahmed (2008), financing risk is the risk arising from the failure of customers fulfilling their obligation fully and timely according to the agreement. Gosh (2013) argued that such financing risk is also called default risk which ensues from the uncertainty of customers in paying back the financing in time to the bank.

According to Thomas et al. (2002) credit scoring are a very important application in statistical modeling and the problem of distinguishing between good and bad. The main objective is to estimate the possibility of default. Credit scoring will provide a score for each loan applicant by defining the cut off value. Each applicant with a score lower than the cut off will be rejected and the higher one will be given financing. Cole (2014) defined Credit scoring as a numerically statistical form which results in a score, a higher score correlates with a lower chance of default.

The financing quality is based on the accuracy of principal payments and margin is divided into 5 groups, namely:

- Current (collectibility 1 ) is on time and no arrears installment payment;

- Special Attention (collectibility 2) is when there are arrears in payment of principal installments and/or margin that have not exceeded 3 (three) months;

- Substandard (collectibility 3 ) is when there are arrears in payment of principal installments and/or margins that have exceeded 3 (three) months but have not exceeded 6 (six) months;

- Doubtful (collectibility 4) is when there are arrears in payment of principal installments and/or margins that have exceeded 6 (six) months but have not exceeded 9 (nine) months;

- Bad (collectibility 5) is that there are arrears in payment of the principal installments and/or the margin has exceeded 9 (nine) months.

\section{METHODS OF RESEARCH}

Types and Source of Data. This research used primary and secondary data. Primary data was obtained by conducting in-depth interview with the Micro Manager, Branch Manager and the Group Head. While secondary data was sourced from the database of the research location, namely the $\mathrm{X}$ Islamic Bank.

Dependent Variable: 
- $Y_{0}=$ performing financing (collectibility 1-2);

- $Y_{1}=$ non performing financing (collectibility 3-5).

Independent Variable: RPC ratio $\left(\mathrm{X}_{1}\right)$, Current ratio $\left(\mathrm{X}_{2}\right)$, Profitability $\left(\mathrm{X}_{3}\right)$, Business reputation/integrity $\left(X_{4}\right)$, Bank relationship history $\left(X_{5}\right)$, Experience/duration of business $\left(X_{6}\right)$, Business prospect $\left(X_{7}\right)$, Dependence on suppliers $\left(X_{8}\right)$, Dependence on customers $\left(X_{9}\right)$, Term $\left(\mathrm{X}_{10}\right)$, Collateral adequacy ration $\left(\mathrm{X}_{11}\right)$.

Descriptive analysis is a method to describe the data that is collected simply. This analysis can be presented in table or graph, even include the calculation of standard deviation, average, and so on (Mustafa and Hardius 2007)

Logistic regression is a statistical analysis technique used to analyze data whose response variables have two or more categories with one independent variable in the category and continuous scale (Kuncoro, 2005).

The binary regression model is a model used to determine the relationship between explanatory variables $(X)$ with a binary response variable $(Y)$. The dependent variable $Y$ follows the Bernoulli distribution with a chance distribution function:

$$
f(Y=y)=\pi^{y}(1-\pi)^{1-y}
$$

With $y=0$ or $y=1$, and $\pi$ is the chance for $y=1$.

If the occurrence of the $Y$ response variable is $n$, the chance of each event is the same, and each event is independent of each other then $Y$ will follow the Binomial distribution. Hosmer and Lemeshow (1989) explained that the logistic regression model with $E(Y=11 \mathrm{x})$ as $\pi(x)$ is:

$$
\frac{e^{g(x)}}{1+e^{g(x)}}
$$

With the logistic regression, logit connecting functions are required, transform logit as a function of $\pi(x)$ is:

$$
(x)=\ln \left(\frac{\pi(x)}{1-\pi(x)}\right)=\beta 0+\beta 1 X 1+\cdots+\beta \rho X \rho \cdots
$$

\section{RESULTS AND DISCUSSION}

The data description for each explanatory variable can be seen in Figure 2 to Figure 4. All customers with the 2.00x RPC ratio variable are customers in the peforming financing category (Figure $2 \mathrm{a}$ ). This is different from the results of in-depth interviews which reveal that higher the RPC ratio value is better because it means that performing financing customers are more able to pay obligations to the bank. If the RPC ratio value is too high, then the prospective customer does not really need financing, but the prospective customer only needs fresh money. Conversely, if the RPC ratio is less than 2.00x then the prospective customer cannot be given financing due to the low ability to pay. RPC ratio is part of the indicators used to see the ability to pay of the prospective customers.

Based on the percentage, customers who experienced the biggest bad credit are those with a current ratio value of less than 1 , which amounted for $5.41 \%$ (Figure $2 \mathrm{~b}$ ). Setiyawan (2014) argued that the current ratio is one of the ratios that measure the level of company liquidity by comparing current assets with current debt. The higher the current ratio means the higher the company's ability to fulfill short-term financial obligations. This means that the current ratio in the results of this study is in accordance with the theory.

According to Kusumajaya (2011), the definition of profitability is a description of management's performance in managing the company. Whereas according to Winarno et al. (2015) profitability is the company's ability to make a profit. Profitability can also be interpreted as the level of net income earned by the company when conducting its operations (Soliha and Taswan 2002). Profitability has an important role in the company because the higher the profitability of the company, the company will be more capable of paying all 
obligations and the company remains in a liquid state (Hanum 2012). Based on interviews conducted with the Bank, the higher the profitability of prospective customers, the higher the ability of management to manage the company. This means that the lower the profitability value, the higher the chance of bad financing. However, in this study, bad financing is in the second choice, namely customers with the profitability of $15-25 \%$ with a percentage of $3.59 \%$ (Figure 2c).
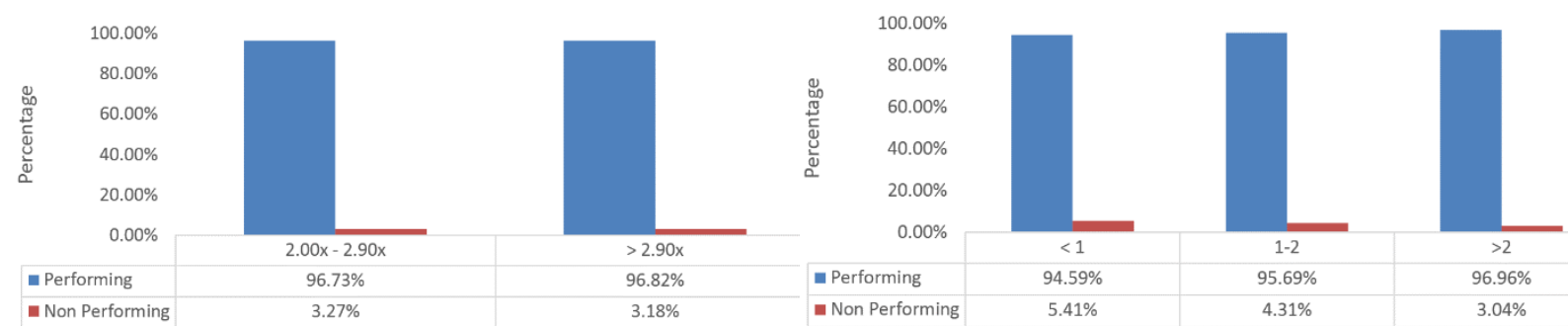

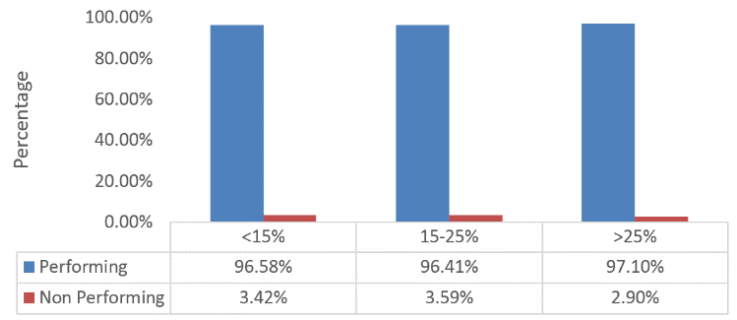

(c) profitability

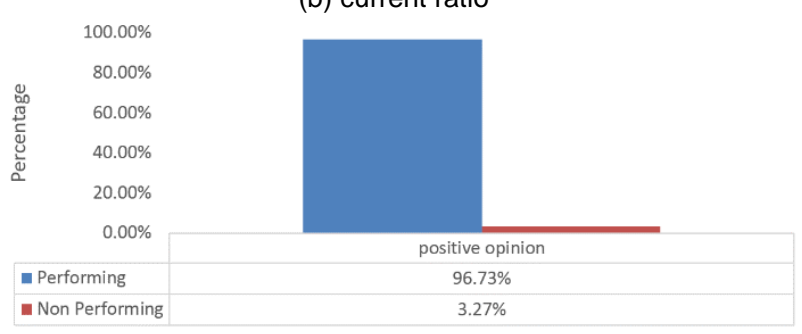

(d) business reputation/integrity

Figure 2 - Percentage for financing quality for the variable of (a) RPC ratio, (b) current ratio, (c) profitability, (d) business reputation/integrity

Based on the results of interviews with the Bank, reputation/business integrity was obtained from the people's opinions located approximately 10 meters from the prospective customer's house/ business and carried out without the knowledge of the prospective customer. This is to avoid collaboration between people and prospective customers to improve the character of prospective customers. The percentage of bad financing is only found in the positive opinion of $3.27 \%$ for the business reputation/integrity category (Figure 2d). While customers with negative/positive opinions are in the current financing category.

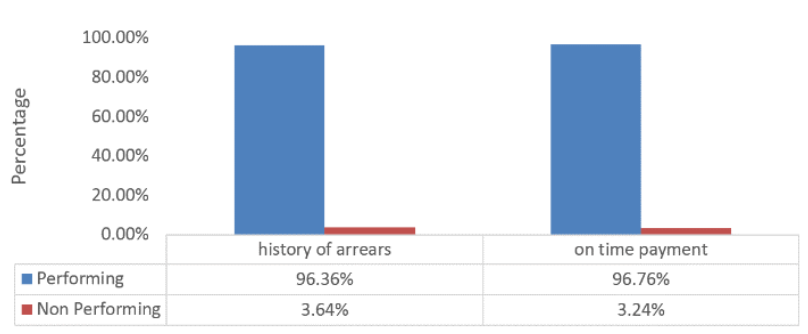

(a) bank relationship history

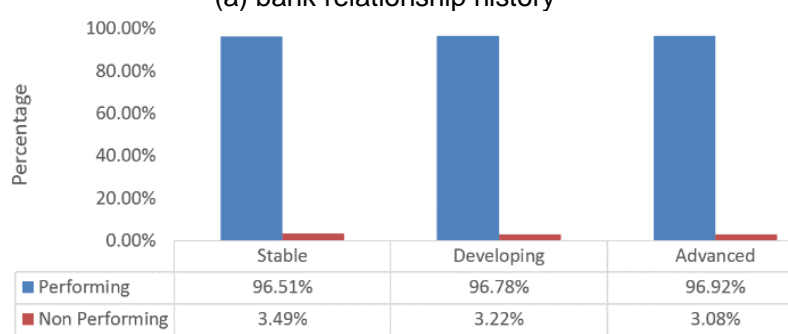

(c) business prospect

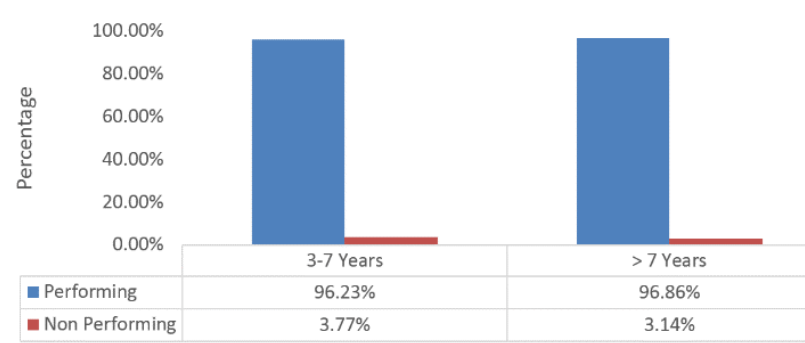

(b) experience/business duration

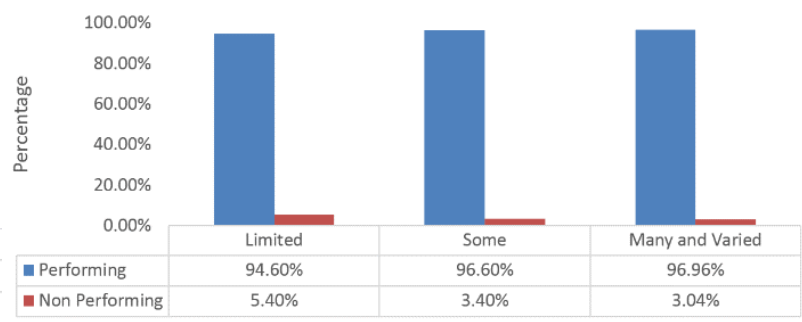

(d) dependency on suppliers

Figure 3 - Percentage of financing quality for the variable of (a) bank relationship history,

(b) experience/business duration, (c) business prospect, (d) dependency on suppliers

In terms of customers characteristics based on the bank relationships history, none of the customers in the bad financing is in the category of 'frequent arrears' because 
prospective customers with a history of collectibility 3,4 , and 5 will automatically be rejected. Figure $3 a$ shows that the highest percentage of bad financing is found in the "history of arrears" of $3.64 \%$. This means that prospective customers have a history of collectible 2 . Whereas 'on time payment' is seen from the history of collectibility 1. Bank relationship history can be obtained through Debtor Information (iDeb). In accordance with what is explained in POJK Number 18 /POJK.03/2017 Customer Information is information about the Customer, Fund Provision Facility received by the Customer, and other related information presented based on Customer Reports received by OJK from Reporters (Commercial Banks, BPR, BPRS, Financing Institutions that provide Fund Provision Facilities, Other Financial Services Institutions that provide Fund Provision Facilities, except microfinance institutions). According to Rosanti (2015), customer information is held in order to facilitate the process of providing funds, implementing risk management and identifying customer quality. One of the steps taken by the bank in analyzing the feasibility of financing provision is to check the financing information related to the prospective customer. The financing information is in the form of a bank or financing institution, the value of the financing facilities that have been obtained, the current payment, and other information related to the financing facility.

Business duration is the period of a businessman runs his business or the ones working period in pursuing a field of work (Setiaji and Fatuniah 2018). All customers with a business duration of fewer than three years have performing financing. Based on the results of the interview with $X$ Islamic Bank, prospective customers who want to obtain micro financing should at least have a business that has been running for 2 years because a business with this duration can be considered as settled. According to (Ismanto and Diman 2014) (Satria et al. 2016), the longer a person's business increasingly influences the currentness of loan repayment. However, the results of the study show that the highest proportion of non-performing customers is in businesses with 3-7 years duration of $3.77 \%$ (Figure 3b).

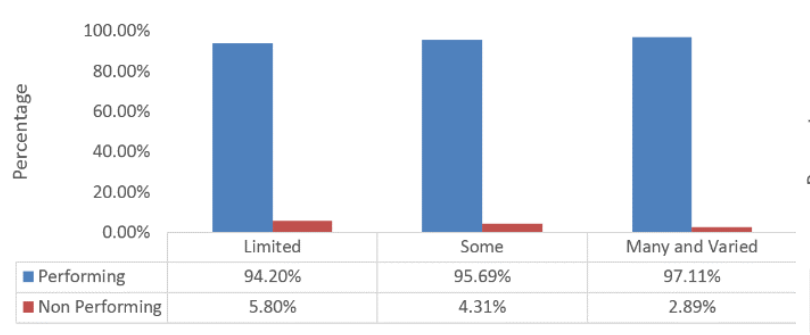

(a) dependency on customers

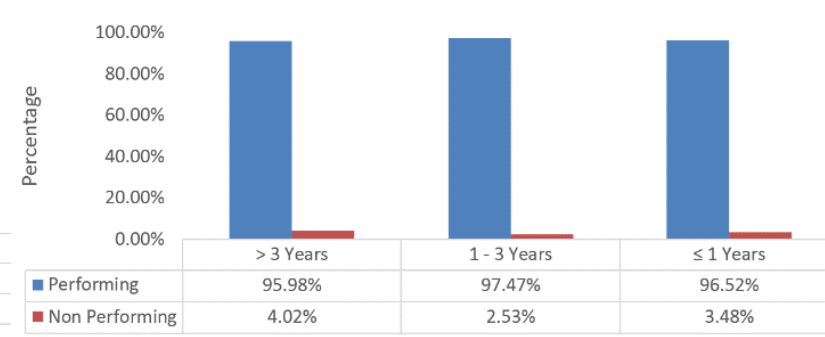

(b) term

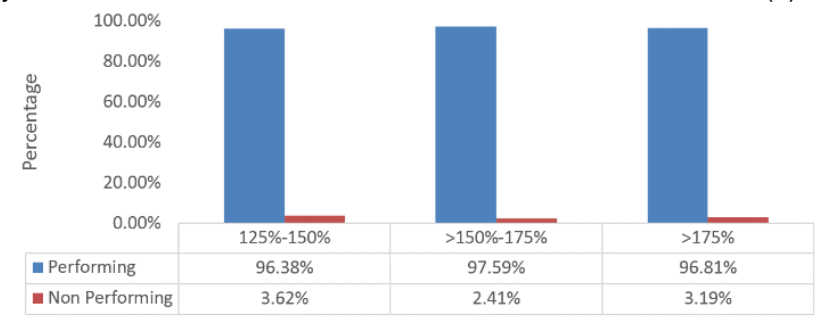

(c) collateral adequacy ratios

Figure 4 - Percentage of financing quality for variables of (a) dependency on customers, (b) term, (c) collateral adequacy ratios

The stable business prospect variable has a non-performing financing quality percentage of $3.49 \%$ (Figure 3c). Based on the results of the interview, it was found that stable means business with almost similar or does not change average annual turnover. While developing is a business that experiences increasing turnover every year and increasing business, such as retailers turn into wholesalers. Advanced is a business with a turnover far greater than developing and the business expansion, for example, which initially only as a clothing seller then advanced into convection and then can set up a factory. The results of the descriptive analysis show that the business progresses more smoothly 
compared to the stable business. This is in accordance with the opinion of $\mathrm{X}$ Islamic Bank that advanced is the highest business status.

From Figure 3d, it can be seen that the percentage of bad financing for the variable of dependence on suppliers is in the limited category of $5.40 \%$. According to the interviews with the Bank, many and varied customers' suppliers will have increased performing financing. Research shows the same results with the opinions of the Bank. Limited means that customers take goods from a limited or certain number of suppliers or 1-2 suppliers. While some say that it means customers have several suppliers or 3-5 suppliers. Many and varied means that customers have large quantities and a variety of suppliers or more than 5 suppliers.

Customers characteristic in the variable of dependency on customers (Figure 4a) for the limited category have the highest percentage of non performing financing of $5.80 \%$. While some dependency on customers has a non performing financing of $4.31 \%$ and many and varied are $2.89 \%$. Based on the results of interviews with the Bank, limited means business have limited customer with certain people or certain markets with around one to two customers only. While some means have more markets than limited or with 3-5 customers only. Many and varied have a much more and diverse market. Many and varied customers mean business has more than 5 customers, anyone can become their customer.

The term is the microfinance time period of a customer in X Islamic Bank. The financing period offered starts from less than 1 year to more than 3 years (Figure $4 b$ ). The customers' characteristics in the category of the highest non performing financing in the term variable are customers with a financing period of more than 3 years which amounted to $4.02 \%$. This indicates that the risk of non-performing customers is more prone to customers with long term.

Figure 4c shows that the highest percentage of collateral adequacy ratios for customers with non performing financing is found in the category $>125 \%-150 \%$, which is amounted to $3.62 \%$. Higher collateral adequacy ratio is better because it shows the value of the collateral when the customer defaults. Supriyadi and Kartikasari (2015) stated that collateral is a guarantee, namely property belonging to the customer or third party which is bound as collateral in accordance with the financing agreement. Collateral has two functions, as payment of financing if the customer is unable to pay by selling the collateral and as a determinant of the amount of financing. Banks in this case usually will not provide a financing value greater than the amount of the collateral provided. According to Bahsan (2007) in the provision of bank financing, the financing collateral is usually required for a financing provision, so ideally the collateral is expected to have high economic value and fulfill judicial aspects so that the bank will be not in a weak position when a problem occurs, because the collateral can be sold to cover the costs of uncollectible financing.

Logistic Regression Analysis. Table 1 shows Negelkerke R-square which is R Square in multiple regression based on the likelihood estimation technique with a maximum value of less than one which is difficult to present. Therefore, Negelkerke R-square which is a modification of Cox and Snell $R$ Square where the values vary from $0-1$, will be easier to interpret as the interpretation of R-Square in multiple regression or Pseudo R-square in multinominal logistic regression. Table 1 shows the Negelker R-square value of 0.023 or $2.3 \%$, which means that the existing variables are only able to explain the diversity of financing quality $2.3 \%$ while the remaining $97.7 \%$ is influenced or explained by other variables not included in this study.

Table 1 - Diversity in the occurrence on quality of financing

\begin{tabular}{llll}
\hline Step & -2 Log likelihood & Cox and Snell R Square & Nagelkerke R Square \\
\hline 1 & 2871.785 & 0.006 & 0.023 \\
\hline
\end{tabular}

Variables Influencing the Quality of Financing. Based on the output, it is explained that the independent variables that have no significant effect on the quality of financing are an RPC ratio, profitability, business reputation/integrity, bank relationship history, experience/ duration of business, business prospects and dependency on suppliers. While the 
independent variables that significantly affect the quality of financing are the current ratio, dependency on customers, the duration and the collateral adequacy ratio. All significant independent variables on the model are variables with the dichotomous binary scale (category/nonmetric). The financing risk faced by X Islamic Bank is the risk of default, i.e. the risk of unreturned of the disbursed funds. The following is the explanation of the four significant variables.

Current Ratio. The first variable that has a significant effect on the quality of financing is the current ratio. Based on the results of the Wald test, the current ratio of $<1$ has a $p$-value of 0.086 less than alpha $10 \%$. This means that the current ratio of $<1$ has a significant effect on quality of financing. The current ratio of $<1$ has a $B$ value of 0.734 and $\exp (B)$ of 2.082, indicating that the risk of non performing financing is 2.082 times greater than the current ratio of $>2$. Therefore, it can be concluded that the current ratio $<1$ has a higher chance of bad financing compared to the current ratio of $>2$.

The 1-2 current ratio has a p-value of 0.015 less than alpha $10 \%$. This means that the 1-2 current ratio has a significant effect on quality of financing. The 1-2 current ratio has a $B$ value of 0.365 and $\exp (\mathrm{B})$ of 1.440, this indicates that the risk of bad financing of 1-2 current ratio is 1.440 times greater than the current ratio of $>2$. Therefore, it can be concluded that the 1-2 current ratio has a higher risk of bad financing compared to customers with a current ratio of $>2$.

Table 2 - Effect of current ratio on quality of financing

\begin{tabular}{llllll}
\hline Variable & B & S.E. & Wald & Sig. & Exp(B) \\
\hline Current Ratio & & & 8.373 & 0.015 & \\
\hline$<1$ & 0.734 & 0.428 & 2.943 & 0.086 & 2.082 \\
\hline $1-2$ & 0.365 & 0.149 & 5.953 & 0.015 & 1.440 \\
\hline
\end{tabular}

Dependency on Customers. Based on the results of the Wald test, customers with 'limited customers' have a p-value of 0.126 more than $10 \%$. This means that 'dependency on limited customer' has no significant effect on quality of financing. Customers with 'dependency on limited customer' have a B value of 0.662 and exp (B) of 1.939, which means that the opportunity for non performing financing for customers with 'dependency on limited customer' is 1.939 times greater than customers with 'dependency on multiple and diverse customer'. Therefore, it can be concluded that customers with 'dependency on limited customer' have a higher risk of non performing financing compared to customers with 'dependency on multiple and diverse customer.

Table 3 - Effect of customer dependence on quality of financing

\begin{tabular}{llllll}
\hline Variable & B & S.E. & Wald & Sig. & Exp(B) \\
\hline Dependency on Customers & & & 12.310 & 0.002 & \\
\hline Limited & 0.662 & 0.432 & 2.345 & 0.126 & 1.939 \\
\hline Multiple & 0.573 & 0.167 & 11.749 & 0.001 & 1.773 \\
\hline
\end{tabular}

Customers with 'dependencies on multiple customers' have a p-value of 0.001 less than alpha $10 \%$. This means that 'dependency on multiple customers' has a significant effect on quality of financing. Customers with 'dependency on multiple customers' have a $B$ value of 0.573 and $\exp (B)$ of 1.773 , which means that the risk of non performing financing for customers with 'dependency on multiple customers' is 1.773 times greater than customers with 'dependency on multiple and diverse customers'. Therefore, it can be concluded that customers with 'dependency on multiple customers' have a higher risk of performing financing compared to customers with 'dependency on multiple and diverse customer'.

Term. Financing term is determined based on the contract between the customer and the bank. The agreement is based on the customer's request which is adjusted to other considerations by the Bank. The term variable has a significant effect on quality of financing. 
Variable of over 3 years term has a p-value of 0.767 above alpha (10\%). This means that more than 3 years term not significantly affects the quality of financing. Customers with a term of more than 3 years have a B value of 0.153 and exp (B) of 1.165 compared to a term of less than 1 year. This shows that a term of more than 3 years has a risk of bad financing 1.165 times higher than the term of less than 1 year.

Based on the results of the Wald test, customers with a term of 1-3 years have a $p$ value of 0.519 more than alpha (10\%). This means that the term of $1-3$ years does not have a significant effect on the quality of financing. Customers with a term of 1-3 years have a $B$ value of -0.334 and $\exp (\mathrm{B})$ of 0.716 . This means that bad financing risk for customers with financing term of $1-3$ years is 0.716 times smaller than customers with terms of less than 1 year. Therefore, it can be concluded that customers with a financing term of 1-3 years have a lower risk of non performing financing compared to customers with terms of less than 1 year.

Table 4 - Effect of terms on quality of financing

\begin{tabular}{llllll}
\hline Variable & B & S.E. & Wald & Sig. & Exp(B) \\
\hline Term & & & 17.821 & $\mathbf{0 . 0 0 0}$ & \\
\hline$>3$ years & 0.153 & 0.516 & 0.088 & 0.767 & 1.165 \\
\hline $1-3$ years & -0.334 & 0.518 & 0.416 & 0.519 & 0.716 \\
\hline
\end{tabular}

Collateral adequacy ratio of $125 \%-150 \%$ has a p-value of 0.302 above alpha $(10 \%)$. This means that the collateral adequacy ratio of $125 \%-150 \%$ does not have a significant effect on quality of financing. Customers with an adequacy ratio of $125 \%-150 \%$ have a $B$ value of 0.123 and exp (B) of 1.131 compared to the collateral adequacy ratio of $>175 \%$. This shows that the collateral adequacy ratio of $125 \%-150 \%$ has a risk of bad quality financing 1.131 times higher than the collateral adequacy ratio of $>175 \%$.

Collateral adequacy ratio of $>150 \%-175 \%$ has a $p$-value of 0.104 above alpha (10\%). This means that the collateral adequacy ratio of $>150 \%-175 \%$ has no significant effect on quality of financing. Customers with collateral adequacy ratio of $>150 \%-175 \%$ have a $B$ value of -0.298 and $\exp (\mathrm{B})$ of 0.742 . This means that the risk of non performing financing for customers whose adequacy ratio is $>150 \%-175 \%$ is 0.742 times smaller than customers whose collateral adequacy ratio is more than $175 \%$. Therefore, it can be concluded that customers with a collateral ratio of $>150 \%-175 \%$ have a smaller risk of non performing financing compared to customers with collateral adequacy ratio of more than $175 \%$.

Table 5 - Effect of collateral adequacy ratio on quality of financing

\begin{tabular}{llllll}
\hline Variable & B & S.E. & Wald & Sig. & Exp(B) \\
\hline Collateral Adequacy Ratio & & & 5.412 & 0.067 & \\
\hline $125 \%-150 \%$ & 0.123 & 0.120 & 1.065 & 0.302 & 1.131 \\
\hline$>150 \%-175 \%$ & -0.298 & 0.183 & 2.647 & 0.104 & 0.742 \\
\hline
\end{tabular}

Managerial Implications. In accordance with both descriptive analysis and logistic regression analysis, the strategies that can be prepared in order to improve the quality of current financing and reduce non-performing financing on microfinance in $\mathrm{X}$ Islamic Bank are:

- The logistic regression analysis shows that there are four variables that have a significant effect on quality of financing, namely the current ratio, dependency on customers, the terms and the collateral adequacy ratio. While the other 7 variables are not significant. necessary for the Bank to do:

a. Hold training for employees to be able to hone analytical skills during customer surveys

b. Needs to be a double checker to ensure that what is done by the first employee is in accordance with the procedure or not 
c. There is a need for periodic evaluations and performance evaluations in X Islamic Bank employees. Employees with good quality of work will be rewarded, whereas employees with poor quality work will receive punishment

- The results of $\mathrm{R}$ square show a value of $2.3 \%$. This means that the variables used in the system scoring at X Islamic Bank, only $2.3 \%$ are influencing the financing quality, while $97.7 \%$ are influenced by other variables not included in the model. Therefore, it is necessary for the Bank to conduct further research to be able to use significant variables that affect the quality of financing;

\section{CONCLUSION}

Based on the results and understanding of the classification of customer status and also the analysis of variables that influence the quality of financing, it can be concluded that:

- Variables that influence the quality of financing are the current ratio variable, dependency on customers, terms, and collateral adequacy ratio;

- The R Square owned by the model is $2.3 \%$.

\section{RECOMMENDATIONS}

In relation to the credit scoring stage, it is now possible to conduct behavioral scoring and collection scoring models for the provision of financing facilities. Other methods such as vintage analysis, bayes method, discriminant method, and other statistical methods are required.

\section{REFERENCES}

1. Andhayani D. 2009. Pengembangan model credit scoring untuk proses analisa kelayakan fasilitas kredit pemilikan rumah (KPR) (studi kasus di PT. Bank Bukopin,Tbk) [tesis]. Bogor (ID): Institut Pertanian Bogor.

2. Ascarya, Yumanita D. 2005. Bank Syariah: Gambaran Umum. Jakarta (ID): Pusat Pendidikan and Studi Kebanksentralan (PPSK) Bank Indonesia.

3. Bahsan M. 2007. Hukum Jaminan and Jaminan Kredit Perbakan Indonesia. Jakarta (ID): PT Raja Grafindo Persada.

4. [BI] Bank Indonesia. 2011. Peraturan Bank Indonesia Nomor 13/23/PBI/2011 tentang Penerapan Manajemen Risiko Bagi Bank Umum Syariah and Unit Usaha Syariah. Jakarta (ID): Bank Indonesia.

5. Cole AR. 2014. Credit Scores and Credit Market Outcomes: Evidence from The Survey of Small Business Finances and The Kauffman Firm Survey. Chicago (USA): Krahenbuhl Global Consulting Chicago.

6. Hanum Z. 2012. Pengaruh profitabilitas terhadap modal kerja pada perusahaan makanan and minuman yang terdaftar di bursa efek Indonesia. Jurnal ManajemenandBisnis. 11(2): $1-15$.

7. Hosmer DWJ, Lemeshow S. 1989. Applied Logistic Regression. John Wiley and Sons. New York.

8. Ibrahim P, Ghazali R. 2014. Zakah as an Islamic micro-financing mechanism to productive zakah recipients. Asian Economic and Financial Review. 4(1):117-125.

9. Ismanto H, Diman T. 2014. Analisis efektivitas pemberian pinjaman program pembiayaan umkm oleh koperasi. Jurnal Economia. 10(2): 148-164.

10. Khan T, Ahmed H. 2008. Manajemen Risiko Lembaga Keuangan Syariah. Abidin IB, penerjemah. Jakarta (ID): Bumi Aksara. Terjemahan dari: Risk Management in Islamic Banking.

11. Kusumajaya DKO. 2011. Pengaruh struktur modal and pertumbuhan perusahaan terhadap profitabilitas and nilai perusahaan pada perusahaan manufaktur di bursa efek Indonesia [tesis]. Denpasar (ID): Universitas Udayana. 
12. Mustafa E, Hardius U. 2007. Proses Penelitian Kuantitatif. Depok (ID): Fakultas Ekonomi Universitas Indonesia.

13. Permata RID, Yaningwati F, Zahroh ZA. 2014. Analisis pengaruh pembiayaan mudharabah and musyarakah terhadap tingkat profitabilitas (return on equity) (studi pada bank umum syariah yang terdaftar di Bank Indonesia periode 2009-2012). Jurnal Administrasi Bisnis. 12(1): 1-9.

14. Rosanti N. 2015. Efektivitas sistem informasi debitur dalam menunjang keamanan pemberian kredit pada PT. BPR Capta Mulia Abadi. Jurnal Manajemen Ide and Inspirasi. 2(1): 94-105.

15. Satria KM, Kasimin S, Makmur T. 2016. Analisis faktor-faktor penyebab kredit macet oleh nasabah sector usaha agribisnis (studi kasus pada BPR Aceh Besar). Jurnal Ilmiah Mahasiswa Pertanian Unsyiah. 1(1): 337-345

16. Setiaji K, Fatuniah AL. 2018. Pengaruh modal, lama usaha and lokasi terhadap pendapatan pedagang pasar pasca relokasi. Jurnal Pendidikan Ekonomi and Bisnis. 6(1): 1-14.

17. Soliha E, Taswan. 2002. Pengaruh kebijakan hutang terhadap nilai perusahaan serta beberapa faktor yang memengaruhinya. Jurnal Bisnis and Ekonomi. 9(2): 149-163.

18. Supriyadi A, Kartikasari D. 2015. Hubungan analisis kredit terhadap kualitas pembiayaan kpr pada pt xyz cabang Batam. Jurnal Akuntansi, Ekonomi and Manajemen Bisnis. 3(2): 128-134.

19. Thomas LC, Edelman DB, Crook JN. 2002. Credit Scoring and Its Applications. Philadelphia (USA): Society for Industrial and Applied Mathematics.

20. Winarno, Hidayati LN, Darmawati A. Faktor-faktor yang memengaruhi profitabilitas perusahaan manufaktur yang listed di bursa efek Indonesia. Jurnal Economia. 11(2): 143-149. 